\title{
Contribution of environmental products to the household economy in Cameroon: essential, complementary or trivial?
}

\begin{abstract}
The role of environmental products, especially of Non-Timber Forest Products (NTFPs) in the livelihoods of rural people has been underlined by many scholars though their actual contribution to household income remains debated. To some, this contribution is essential while for others it is only complementary or even trivial. In order to contribute to this debate, we analyzed the data collected through 474 household interviews and focus group discussions held in 13 villages in the humid forest zone of Cameroon. The results show that environmental products in general were collected by $96 \%$ (East) $76 \%$ (South) and $58 \%$ (Southwest) of the households interviewed. Though non-negligible in the first two regions, the financial contribution of environmental products to the household economy remains relatively low. However, many households remain attached to NTFPs because they reflect their way of life and food security aspirations. The highest relative contribution of NTFPs $(16 \%)$ to households' income was obtained from villages in the East populated by Baka pygmies while the highest absolute household income value emerged from villages in the South (XAF 600,000/USD 1,091) where the performance was associated with both forest availability and the willingness of Bantu households to invest their time and knowhow in valuing environmental goods. On the other hand, agriculture was dominant in the three regions with an average annual income of $70 \%, 46 \%$ and $38 \%$ respectively for villages in the South, Southwest and East regions.
\end{abstract}

Keywords: NTFPs, household income, household economy, environmental products, agriculture, livelihoods
Volume 2 Issue I - 2018

\author{
Awono $\mathrm{A}^{1,2}$ Levang $\mathrm{P}^{1,2}$ \\ 'Center for International Forestry Research, University in \\ Montpellier, France \\ ${ }^{2}$ Research Institute for Development, Development Geography, \\ France
}

Correspondence: Abdon Awono, Development Geography, Governance, Environment and Development Research Associate UMR GRED-IRD, C/o: P.O Box 2008 Messa, France,Tel +237 6645476I5,Email abdonawono@gmail.com

Received: August 21, 2017| Published: January 10, 2018

\section{Introduction}

Tropical forests have been recognized to play a multi-functional role by providing both goods (timber, food, medicine, etc.) and services, including recreational and spiritual benefits and climate regulation, making human life better. ${ }^{1,2}$ The international debate has paid high attention to the potential of NTFPs in supporting livelihoods and forest conservation. The article by Peters et al. ${ }^{3}$ assessing the economic value of these products in an Amazonian rain forest, and the FAO report ${ }^{4}$ underlining the importance of minor forest products initiated numerous studies analyzing the contribution of these products to self-consumption and medication, income generation and numerous other uses over the last two decades.

Environmental products are diverse in nature and difficult to be captured in a specific definition. To be specific on what we are talking about in this paper, we refer not only to non-timber forest products of a biological origin, but also to timber, further-processed forest products, woodlands and trees beyond the forest as viewed by FAO. ${ }^{5}$ The idea is to have a broad view on the use of fruits, seeds, nuts, exudates, barks, game and their derivative products, used as food, medicine, fodder, timber and craft wood, decorative plants or shade plants. ${ }^{6}$ Selfconsumption, gifts and trade were considered as well as the time and labour invested by farmers in the process of producing these products.

In Cameroon, like in other Congo Basin countries, the exploitation of NTFPs is often viewed as more profitable to rural communities than logging ${ }^{7-9}$ as their exploitation is less damaging than other forest uses. Many scholars consider that if these products were adequately valued, the tropical forest would be better preserved by forest dwellers ${ }^{10-12}$ In recent years, many Integrated Conservation and Development Projects (ICDPs) were developed to combine social development with conservation goals. ${ }^{13,14}$ Indeed, national, regional and international organizations were supporting projects aiming at improving the management of Non-Timber Forest Products (NTFPs) for their greater contribution to tropical forest conservation and poverty alleviation. Nasi et al. ${ }^{15}$ pointed out that expanding technical knowledge and approaches were made available to support the management of forest through adoption of new and powerful tools, including remote sensing and the use of geographic information systems, but more innovations were still necessary with the concept of sustainability set in a broader context of ecology and society.

The purpose of this paper is to analyze the role and actual contribution of environmental products to household income. We are interested in a number of questions, including: Who benefits most from them, the poorer or the richer households? What are the differences between households linked to their ethnic origin, age, education, accessibility of villages, access to markets, etc. in creating household revenues and food opportunities for rural communities? What is the link between environmental products and other livelihood opportunities? What types of products are collected in the humid forest zone of Cameroon and are their differences between regions? The analysis includes the trend after a period of 2years to see how things are evolving in the daily livelihood of farmers. The underlying assumption here is that in the more remote sites environmental income will challenge agricultural income. On the other hand we used the 
hypothesis that the majority of households will opt for a diversification of income sources if opportunities exist to avoid unpredictable external shocks. So people will tend to shift opportunistically from one activity to another for more security.

This paper is organized in four sections: (1) the first one presents a theoretical foundation for analyzing household economy and the contribution of environmental products in reducing poverty; (2) the following method section describes the methods used for data collection; (3) the third section highlights the results obtained while, (4) the last section covers the discussion and subsequent policy implications.

\section{Environmental products and poverty reduction: a theoretical perspective}

A good knowledge of the potential of environmental products, especially NTFPs, in fighting poverty is essential because it helps setting appropriate livelihood improvement strategies in rural areas. Insufficient information on the resources will automatically lead to inefficient forest policies. In fact tropical forests are considered as a major source of numerous valuable goods. To local people NTFPs are indisputably the most valuable forest resources, while decision makers and economic operators worldwide primarily focus on timber. The term non-timber forest product refers to a wide range of biological resources that originate from forests (though nowadays many are also harvested out of the forest) other than timber.

Local people have been collecting forest goods from time immemorial for a variety of foods, medicine and other products that contribute to cultural services, building material, ornamental goods and clothing. ${ }^{7,10}$ At the same time, forest lands are converted to agriculture. More recently, forests have been recognized as major climate regulators due to carbon sequestration by trees..$^{16}$ All this has led to numerous international debates on the way forests should be used. While some think that more restrictions should be imposed on forest access for conservation reasons, others consider such restrictions as a despoilment of the rights of local people and the annihilation of the economic growth of tropical forest countries relying on forest resources.

While some NTFPs are used only at the grassroots level others, though not sufficiently processed, have carved out a place in local, regional and international trade, where significantly higher prices can be obtained..$^{17}$ Unfortunately, such high prices are not only good news for additional household income but also a serious concern for sustainability, as high prices usually translate into a run on the resource. For some market supply chains in Cameroon, like Prunus africana (African cherry), Pericopsis elata (Assamela), Gnetum spp. (Okok), excessive harvesting has led to CITES restrictions, ${ }^{18}$ negatively impacting the livelihoods of poor people.

\section{Livelihood and rights approaches}

A livelihood comprises the capabilities, assets, and activities required to make a living. Through livelihood approaches, more attention has been paid to factors affecting the livelihoods of poor people, including ecological, economic and social aspects. The objective is to enhance people's ability to make a better living, in a sustainable manner. Sustainable livelihoods could serve as an integrating factor that gives a chance to policies to address development, sustainable resource management, and poverty eradication simultaneously. ${ }^{19}$ As such, livelihood approaches are concerned largely with household-based productive activities, risk management and social protection. Meanwhile the rights approach has conventionally concentrated upon wider entitlements and is defined primarily in reference to internationally defined rights upheld by the State. Human rights by contrast have conventionally concentrated on the ultimate ends of freedom and wellbeing and extrapolated back to the social and political relationships that are required to achieve this ideal state. In fact, economic, social, cultural and political development at the grassroots should be seen as the process of achieving basic human rights. ${ }^{20}$ In that sense, though legal rights of local communities have been obtained through the community forestry framework, its implementation is still limited. This may imply that the rights approach alone is not enough to fulfill the communities' development agenda.

\section{Gender perceptions}

Considerable theoretical attention has been paid to gender relations and poverty reduction in the rural areas in sub-Saharan Africa. Gender relations within the household are a major factor constraining women's productivity in African agriculture and leading to inefficiency. ${ }^{21}$ Households can be an arena of conjunction or competition, leading to higher or lower productivity. It may be important to address the issue of household economy through a livelihoods approach, to characterize the households and potential conflicts to obtain a broader view on their role in fighting against poverty. As indicated by Whitehead \& Kabeer $^{21}$ gender and poverty analysis has become more sophisticated while poverty eradication has been established as the primary development objective of the new century. As such, appropriate strategies should be thought to understand better and give new orientations to the relations between women and men like between minorities and better represented groups.

\section{Implementation effort}

Initiated in the early 1990s, the effort of integrating NTFPs into the legislation of Cameroon, like in other Congo Basin countries, was not the result of an ambition to implement a national vision, but rather a follow-my-leader approach of the international debate on forest management. As a result, NTFPs are far from being a priority in Cameroon's forest policies. The objective to meet the basic needs of forest dwellers is timidly cited in a prevailing context of conservation, restricting the use of NTFPs by local communities to subsistence only. Reversely, local communities are not allowed to access the market for NTFPs but conserve the right to convert the national forest domain to agriculture. This suggests that the restrictions for local communities to access the market are not necessarily a rampart for forest and forest goods loss but more likely an ice wall.

\section{Research setting and methods}

This paper is generated from the research conducted as part of the Global Comparative Study on REDD+ (GCS) carried out by CIFOR. Aiming at understanding the contribution of REDD initiatives, the project embarked in analyzing the global household economy of the target villages in 3 regions of the humid forest zone of Cameroon (Figure 1). As such, qualitative and quantitative data have been collected in order to gain a broad view of the dynamic of household economy in the humid forest zone of Cameroon. All the income sources were identified, the wellbeing of household members evaluated and the gender relations assessed. ${ }^{22}$ 


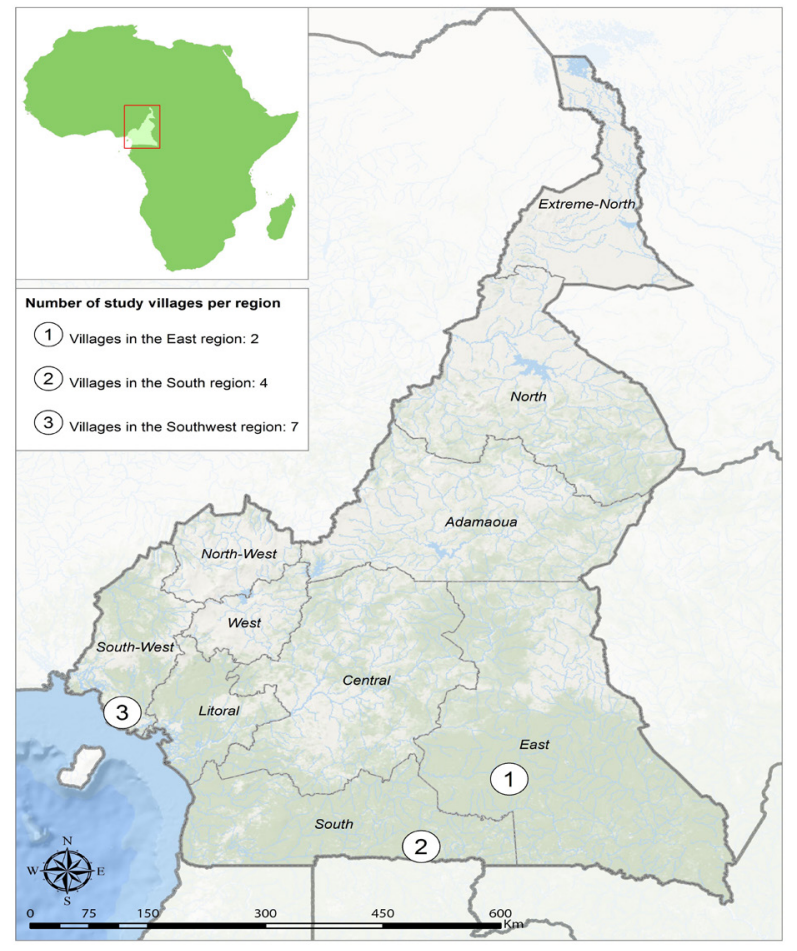

Figure I Study area.

In this paper the term income includes both cash and noncash income (subsistence) for household use. Prices for the home consumption goods have been derived from either farm-gate, barter values, substitutes, willingness to pay, distant market prices or value of time in order to determine the gross income or total value of the income. Environmental products both self-consumed and sold were recorded.

\section{Selected sites}

After the feasibility stage of the study on REDD+ in Cameroon, two initiatives were selected: PES in the East and South regions and Mt Cameroon REDD+ in the Southwest region (Figure 1). The discussions were carried out with the proponents and 13 villages were selected for data collection, including 2 in the East, 4 in the South and 7 in the Southwest. The research reported in this paper was conducted through formal interviews. Three survey forms were used through (1) village focus group meetings with people knowledgeable about the village, including men, women and youths, (2) women focus group meetings consisting of women of various ages and (3) direct interviews of randomly selected households. ${ }^{22}$

\section{Selected households}

After consultation with village authorities and key informants, all households present in the village were listed. Then 30 to 40 households were randomly selected from the list. In the East where we had only one intervention village and one control village, 60 households were selected in each village. During the second survey two years later, the attrition rates helped us to decide on the number of new households to include in the sample to replace those missing. The household head of the chosen households was interviewed with the assistance of the spouse (generally the wife but not in all cases) when necessary.

In total, 474 households were interviewed in the two project sites and 2 separate focus groups were conducted in each village with an average of 15 participants per focus group (Table 1).

Table I Household interviews

\begin{tabular}{lllll}
\hline \multirow{2}{*}{ Sites } & \multirow{2}{*}{ Villages(N) } & Households(N) & \multicolumn{2}{l}{ Head of households } \\
\cline { 4 - 5 } & & & Men (\%) & Women (\%) \\
\hline East & 2 & 82 & $76(93 \%)$ & $6(7 \%)$ \\
South & 4 & 168 & $127(76 \%)$ & $41(24 \%)$ \\
Southwest & 7 & 224 & $184(82 \%)$ & $40(18 \%)$ \\
Total & 13 & 474 & $387(82 \%)$ & $87(18 \%)$ \\
\hline
\end{tabular}

\section{Study site description}

The three sites are located in the humid forest zone of Cameroon but differ in terms of population density and forest land available. The Southwest site is dominated by agro-industrial activities focusing on oil palm, banana and rubber production. The population is diverse with many immigrants from the Northwest region due to farmland shortage in their home area and available jobs provided by agro-industries in the Southwest. Their integration is made easier by a shared common language (pidgin). Meanwhile, the CED site (East and South) has low population densities with more forests and active logging activities. The villages of the site in the East are populated with communities of Baka Pygmies.

The CED site benefits from a Community Forestry (CF) as designed by the 1994 forestry law that aims at giving more responsibilities to local communities in forest management. The second project is based in the Southwest region of Cameroon around Mount Cameroon national park. This national park is surrounded by villages populated by indigenous people (Bakweri and Bamboko) and migrants from the Northwest region. Both sites belong to the humid forest zone (Figure 1) but forest cover is lower in the Southwest compared to the East and South due to the high deforestation rate in the Southwest region (between 1987 and 2010, 46.2\% of the original natural forest was converted into agricultural land use systems around Mount Cameroon. ${ }^{23} \mathrm{~A}$ structured questionnaire was used with variables on family composition, education, economic activities, labour distribution, production, income, products prices and household selfconsumption. Apart from the household survey, village and women surveys were conducted separately with a structured questionnaire involving about 15 community members with different ages to reflect the possible diversity of opinions in the community.

The strong point of this study setting is that the selection has not been designed specifically for NTFPs evaluation. However because the GCS project targets the humid forest zone, including 3 of the 5 regions concerned in Cameroon, the selected villages are representative in terms of environmental products and NTFPs use, far 
from preconceived ideas that could bias the selection (as is usually the case in numerous studies targeting specific zones depending on the availability of NTFPs). Moreover, one of the objectives of the project was to identify all the economic sources of the households. This is viewed as a good opportunity to compare the importance of NTFPs in households in terms of self-consumption, gifts and trade, from one region to another. The production cost was also considered to make sure that we understood the challenges faced by producers. The term producer -instead of collector- is used here in order to value the investment of the people in terms of time, labour and even knowhow in the process of NTFPs' production. In addition, to understand the impact of village accessibility on NTFPs' exploitation, the selected villages were divided into two groups based on the quality of road access for appropriate analysis.

\section{Results}

\section{Village and households' characteristics}

Eight villages ( 2 in the East, 2 in the South and 4 in the Southwest) out of twelve are located in remote areas while the others benefit from a rather good road access, at least because they are close to a paved road ( 2 in the South and 3 in the Southwest). Some villages of our sample are located close to the border with other countries (Nigeria or Gabon), which might be a factor influencing the production of environmental products. The average age of household heads is 34 years with about $45 \%$ of the sample belonging to the middle age (40-59)group. More than 50\% did reach at least secondary school. Close to half of the households are of medium size (4-6) and only $18 \%$ are headed by women. NTFPs' exploitation is taking place in a context of diversified livelihood strategies (Table 2) including forest activities, fishing, agriculture, livestock, petty trade, various businesses, pensions and remittances. While some of these activities are permanent others are seasonal.

However all of them require substantial efforts in terms of time or personal knowhow to reach self-consumption or trade steps. Classically, NTFPs sold in Cameroon derive from the extra production after self-consumption has been satisfied. However, because of hardship faced by households during the hunger gap or start of the new school year, increasingly higher quantities tend to be sold.

Table 2 Household characteristics
Beyond the access rights debate on forest products, the involvement in specific activities such as agriculture or forest products extraction requires land availability for the family, personal knowhow, time or financial capital. On the other hand, the classification of the wellbeing categories of the households depends on the vision of the community members. Therefore the reference is mostly made on the quality of construction material of the house, the type of assets, toilet, water facilities or electricity. In the Southwest region, high level of migration has been registered due to the conjunction of soil fertility and cultural similarities with Northwest groups lacking land for farming. All these factors tend to influence the quality of life of the community members.

The data presented in table 2 shows that environmental products were harvested by a large majority of households in the South and East regions, less in the Southwest. In total $96 \%, 76 \%$ and only $58 \%$ were respectively involved in producing at least one resource from forest or non-forest ecosystems within the 2years prior to the interviews. Meanwhile, 97 to $99 \%$ of the households were involved in agriculture and livestock production in the three regions, rendering it the most consensual livelihood activity across our sample. In terms of livelihoods, the difference was more negatively pronounced for the East villages though about $40 \%$ of their households declared they were better off. Also, in about $50 \%$ of the households across our sample, the consumption and sale of forest products decreased while in about $25 \%$ the trend increased, in the two years prior to the interviews. Meanwhile, about $40 \%$ of households considered they were better off, while about $35 \%$ saw their wellbeing reduced. The highest contrast is on wage labour where $77 \%$ of households practiced wage labour in the East while the average in the Southwest and South did not exceed $40 \%$ (Table 2). In fact, forestland under the household control has been diminishing progressively. Furthermore, tenure insecurity has been underlined as a main constraint by the whole sample. In fact many households tend to borrow or rent plots on forestland. As the government opposes or restricts clearings, especially in areas close to protected areas, most households fear that their rights could be revoked at anytime. Evaluating the distribution of household production in the different villages studied, it was found that selfconsumption represents the highest proportion both for agriculture or environmental products, except in the Southwest where more than $50 \%$ of the agricultural production is intended for the market.

\begin{tabular}{llll}
\hline Household characteristics & East villages & South villages & Southwest villages \\
\hline Total forest land area in 20I4(ha) & 4,35 & 17,49 & 3,14 \\
Total converted land area in 20 I4(ha) & 1,68 & 7,20 & 4,33 \\
Increase in forest cash income in the last 2years (\%) & 22 & 13 & 4 \\
Decrease in forest cash income in the last 2years (\%) & 28 & 26 & 39 \\
Increased consumption of forest products in the last 2years (\%) & 21 & 13 & 12 \\
Decreased consumption of forest products in the last 2years (\%) & 20 & 13 & 32 \\
Decreased opportunity for clearing forest in the last 2years (\%) & 29 & 30 & 38 \\
Increase in wellbeing in the last 2years (\%) & 41 & 36 & 37 \\
Decrease in wellbeing in the last 2years (\%) & 33 & 36 & 97 \\
Producing agricultural products in the last 2years (\%) & 99 & 99 & 58 \\
Producing environmental products in the last 2years (\%) & 96 & 76 & 50 \\
Rearing livestock in the last 2years (\%) & 36 & 74 & 37 \\
Doing business in the last 2years (\%) & 40 & 36 & 33 \\
Involved in wage labor in the last 2years (\%) & 77 & 48 & 58 \\
Receiving other income in the last 2years (\%) & $5 \mathrm{I}$ & 64 & 37 \\
\hline
\end{tabular}


The comparison of the annual households' income in the studied villages (Figure 2) shows that Bova Bomboko in the Southwest region has the highest income (XAF 6 million) (USD 11,000), nearly 1.5times the income of Medjeng ranking second with 4.7million (USD 8,630). The households' annual income in 9 out of 13 villages ranges from XAF 1 to 3 million (USD 1,800 to 5,500). The two villages ranked last are the ones in the East region with about XAF 500,000 (USD 910). Agriculture is the dominant source of income in nearly all the villages studied with the exception of Nomedjoh where more income derives from environmental goods, agriculture being trivial. Environmental income is more visible in the South with Medjeng reaching almost XAF 800,000 (USD 1,455) of annual average income followed by the East while such products are insignificant in the Southwest, swamped by off-farm and agriculture.

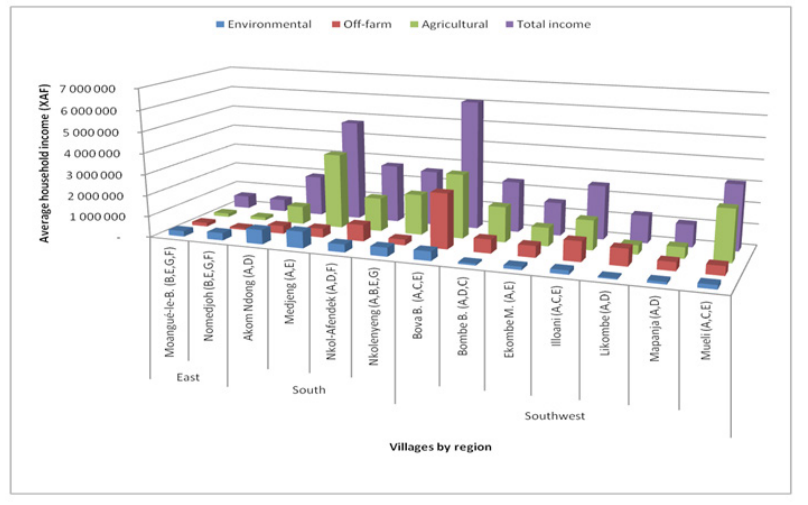

Figure 2 Household income sources within the sample.

Environmental: Wood + NTFPs for services + NTFPs for food + Medicina plants + Fuel wood/charcoal + Fauna. Off-farm: Business + Wage labour + Pension + Remittances + Gifts/A, with Bantu; B, with Baka; C, with migrants; $\mathbf{D}$, with easy access or close to city; $\mathbf{E}$, Remote village; $\mathbf{F}$, with community forest for timber; $\mathbf{G}$, with community forest for PES)

Figure 3 shows that, in total, the villages of the South present the best economic situation with an annual income from agriculture close to XAF 2million (USD 3,636) and an environmental income of XAF 600,000 (USD 1,091), more than in any village of the other regions. Conversely, off-farm activities are merely complementary with less than XAF 400,000 (USD 727). Meanwhile, though agriculture remains more important (XAF 1.5million / USD 2,727) in the Southwest villages, more efforts are put on off-farm activities (XAF 1million / USD 1,818) compared to other villages. Obviously, environmental income is trivial in the Southwest with less than XAF 200,000 (USD 364) of annual contribution. On the contrary, in the East environmental products are ranked first in proportion but with absolute values too low to improve livelihoods and food security. The contribution of environmental products to the annual household income (Figure 4) amounts to $52 \%, 19 \%$ and $7 \%$ respectively for the villages in the East, South and Southwest regions.

\section{Role of environmental products in sustaining household income}

Analyzing further the structure of environmental income (Figure 5), the results show different profiles for the 3 regions. Environmental income is strongly influenced by fauna in the South $(60 \%)$ and East $(39 \%)$ and by fuel wood (44\%) and wood (37\%) in the Southwest. Leaving aside wood, fuelwood and fauna products, the contribution of the remaining category commonly recognized as NTFPs, including food, services and medicine, is limited to $16 \%, 4 \%$ and $1 \%$ of the total household income, respectively for the South, East, and Southwest villages. These results are in line with findings of Levang et al. ${ }^{24}$ in villages surrounding forest concessions of the East and South regions.

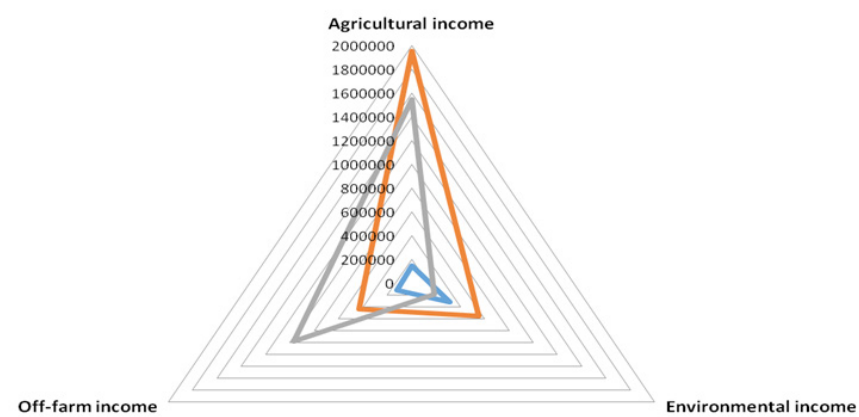

Figure 3 Major average households' income sources by region.

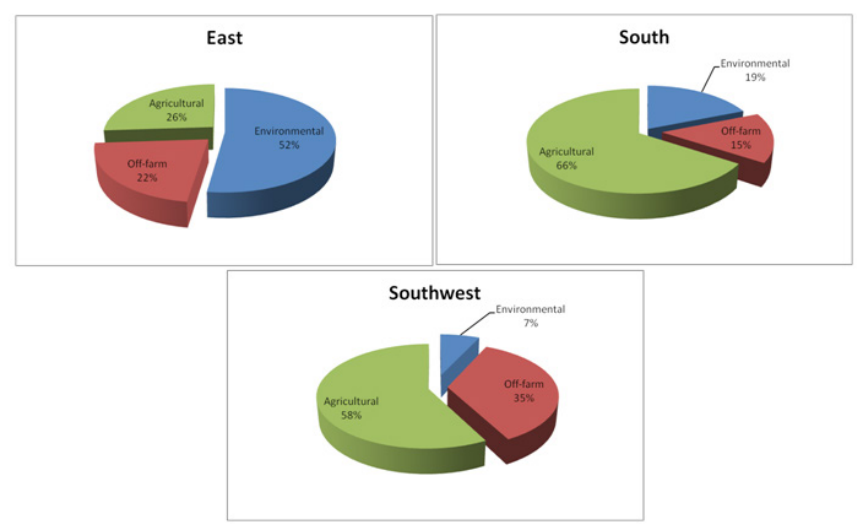

Figure 4 Total household income distribution from various sources.

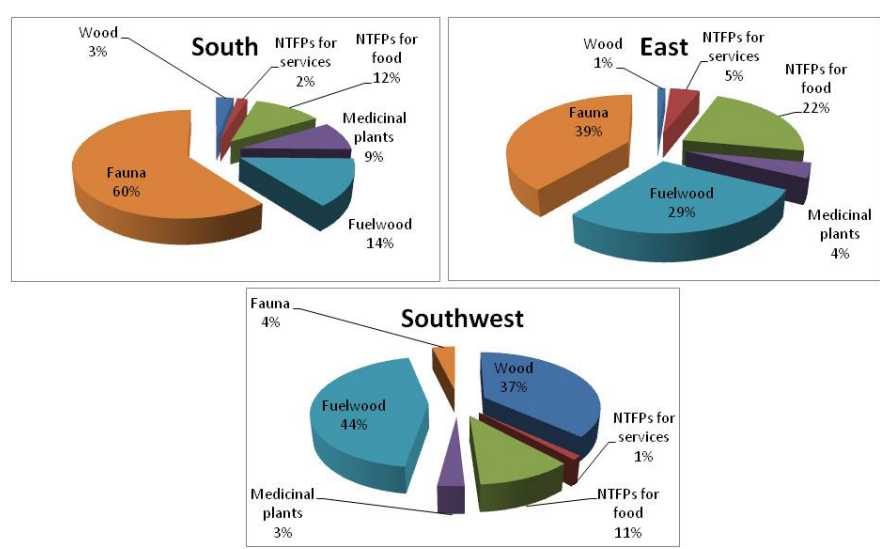

Figure 5 Environmental income distribution.

There is a huge heterogeneity not only between regions but also between villages. Medjeng in the South region is the village where environmental products are most valued with a contribution to the household economy close to XAF 800,000 (USD 1,455) per year compared to Likombe in the Southwest closing the list (Figure 6) with less than XAF 100,000 (USD 182). Fauna and fuel wood are the most important items of environmental income for the households of the South and East regions. Apart from Bova Bomboko (Southwest) ranked third, the villages of the South are by far on the top list compared to other regions. 


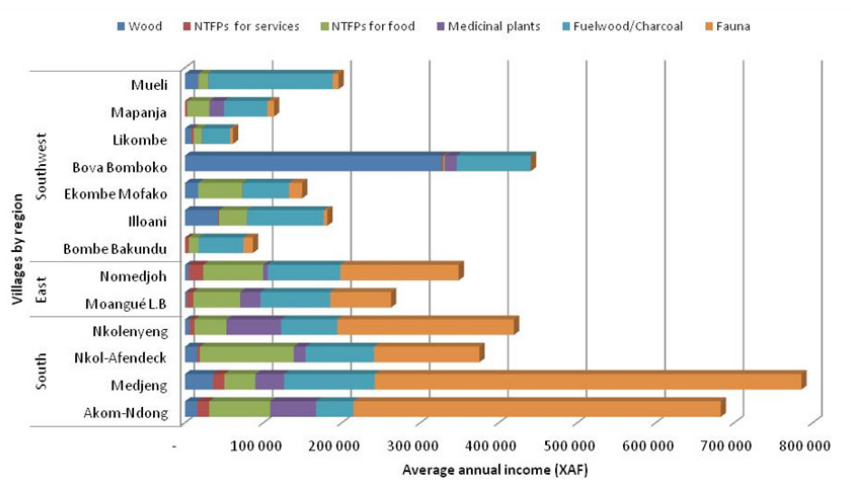

Figure 6 Environmental households' income (XAF) distribution.

Determinants of the variability of annual household income

The household income shows considerable variations across our st udy sites. If the livelihoods activities appear to be similar from one region to another, there are important factors that affect positively or negatively the livelihoods. The quality of roads, the main livelihood activity targeted or the interactions with regional markets have been identified as influential livelihood factors.

Table 3, by regrouping the villages into remote and easy access categories, shows that the only significant difference between the groups on the average income concerns agricultural income (Test $\mathrm{t}=23.263 ; \mathrm{dl}=464 ; \mathrm{p}=0.001<0.05)$. Surprisingly, on average villages with an easy access have a lower agricultural income than more remote villages (XAF 978,300 / USD 1,779 against XAF 1,749,800 / USD 3,181).

Beyond transportation and road condition, household income may be dependent on other factors. Hence, local trade was opposed to regional trade with regard to the type of transactions taking place in the village. Four groups were set, including 1) remote with only local trade, 2) remote with regional trade, 3 ) easy access with only local trade, and 4) easy access with regional trade. The fourth group was dropped because it did not match any reality on the ground. An analysis of variance was applied in order to compare the incomes for the three categories (Table 4).

Table 3 Main source of income and accessibility

\begin{tabular}{|c|c|c|c|c|c|}
\hline Indicators & Type & $n=$ & Mean /X & Test F & Value of $p$ \\
\hline \multirow[b]{2}{*}{ Agricultural income } & Easy access & 169 & 978,300 & \multirow[b]{2}{*}{23.263} & \multirow[b]{2}{*}{0.001} \\
\hline & Remote & 297 & $\mathrm{I}, 749,800$ & & \\
\hline \multirow{2}{*}{ Environmental income } & Easy access & 164 & 293,364 & \multirow{2}{*}{0.283} & \multirow{2}{*}{0.339} \\
\hline & Remote & 299 & 375,618 & & \\
\hline \multirow[b]{2}{*}{ Other income } & Easy access & 158 & 642,698 & \multirow[b]{2}{*}{0.226} & \multirow[b]{2}{*}{0.896} \\
\hline & Remote & 283 & 694,759 & & \\
\hline \multirow{2}{*}{ Total income } & Easy access & 170 & $\mathrm{I}, 855,452$ & \multirow{2}{*}{5.237} & \multirow{2}{*}{0.098} \\
\hline & Remote & 303 & $2,734,709$ & & \\
\hline
\end{tabular}

Table 4 Aggregated household income sources by village access type

\begin{tabular}{|c|c|c|c|c|}
\hline Sources of income & Village category & Means/X & Test F & $P$ value \\
\hline & EAVLT* & 978,300 & & \\
\hline \multirow[t]{3}{*}{ Agricultural income } & RVRT* & $2,360,754$ & 11.7 & $0.000<0.05$ \\
\hline & RVLT* & $\mathrm{I}, 347,047$ & & \\
\hline & EAVLT & 293,364 & & \\
\hline \multirow[t]{3}{*}{ Environmental income } & RVRT & $48 I, 82 I$ & 1.9 & 0.146 \\
\hline & RVLT & 303,423 & & \\
\hline & EAVLT & 642,698 & & \\
\hline \multirow[t]{3}{*}{ Other income } & RVRT & $492,4 \mid 4$ & 0.25 & 0.779 \\
\hline & RVLT & 831,251 & & \\
\hline & EAVLT & $\mathrm{I}, 855,452$ & & \\
\hline \multirow[t]{2}{*}{ Total income } & RVRT & $3,247,971$ & 2.24 & 0.108 \\
\hline & RVLT & $2,393,474$ & & \\
\hline
\end{tabular}

The results in Table 4 show that, irrespective of the income source, average total household income does not show any significant difference among the categories set (Sig. $=0.108>0.05$ ). Specific analyses were carried out with the mean of each income source (agricultural, environmental and other income source category). The average total household income from agriculture was XAF 
978,300 (USD 1,780) in villages with easy access and only local trade (EAVLT), XAF 2,360,754 (USD 4,290) in remote villages with regional trade (RVRT) and XAF 1,347,047 (USD 2,450) in remote villages with only local trade (RVLT). The variance test confirmed that access to regional trade was a booster for agricultural income even in remote villages.

Analyzing the significance of differences between the different groups of villages for annual agricultural income, the Post Hoc Test concluded that there was a significant difference between RVRT and RVLT (Sig. $=0.002<0.05)$ and RVRT and EAVLT (Sig. $=0.000<0.05)$. Thus the connection of a remote village with the regional markets improves agricultural income for the households. For instance, Medjeng is ranked second of the whole sample, supported by agricultural income, though the road conditions are appalling even for Cameroonian standards. Because the village is close to the border with Gabon, business activities are thriving, which is a clear incentive to produce and sell more to meet the demand. This also shows that agriculture has indisputably the highest contribution to household income in the Cameroonian humid forest zone.

The category 'remote village with only local trade' (Figure 7) is strongly influenced by the Southwest region where migrants are operating intensive businesses. As pointed out by Ifeanyi-Obi \& Matthews-Njoku, ${ }^{25}$ with recent and strong population increases, many villages merge into urban areas; still considered rural areas they benefit from most attributes of towns. Bova Bomboko in our study is in that case.

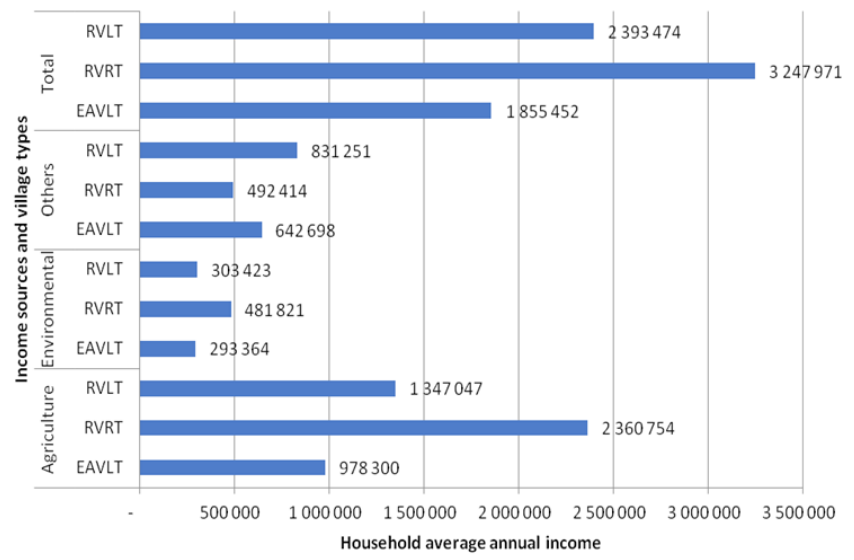

Figure 7 Average annual household income based on the accessibility and type of trade occurring in the village.

EAVLT: Easy Access Village with only LocalTrade; RVRT: RemoteVillage with Regional Trade; RVLT: Remote Village with only Local Trade

Environmental income is usually considered as income obtained from the harvesting of resources provided through natural processes and not requiring, as such, intensive management. As the name suggests, forest environmental income comes from products gathered in the forest while non-forest environmental income is generated outside the forest. Thus a clear distinction should be made between forested and non-forested lands. Figure 8 shows that a higher proportion of NTFPs is generated from forest ecosystems, irrespective of the region. However, the level varies from one region to another. While $94 \%$ of the harvests in the East come from forest land, such ecosystems in the South and Southwest regions only provide respectively $61 \%$ and $58 \%$ (Figure 8). Some products are harvested exclusively from forest land in each region.

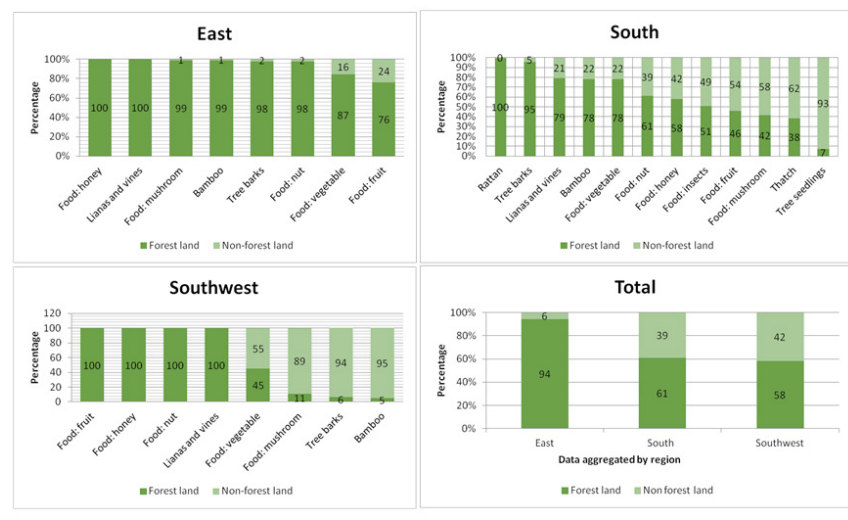

\section{Figure 8 Origin of NTFPs.}

These include rattan in the South, honey, some fruits and nuts in the Southwest, and honey and vines in the South. In the meantime, a serious concern is associated with some products like bamboo and tree barks significantly harvested from non-forest land in the Southwest. In fact deforestation is recognized to be higher in the Southwest region compared to other regions of Cameroon due to agro-industries and intensive family agriculture as the population is growing fast with inmigration. Meanwhile the results obtained from the East are due to the fact that the villages sampled are dominated by Baka groups not yet significantly involved in agriculture and, as such, non-forested lands are minimal. Thus, the harvests of environmental products taking place in farmland and other fallows are consecutive to individual efforts in preserving or planting trees with acknowledged utilities. This suggests that the policy applied on NTFPs for instance should consider this crucial fact as most restrictions opposed to rural dwellers are associated with forest conservation, while NTFPS increasingly originate from other types of ecosystems.

The grouping of households in quintiles according to their total income (Figure 9) shows that the relative contribution of environmental income is more important for the poorer households (39\% against $11 \%$ for the richer). However, considering absolute values the environmental income of richer households is 7 times higher than that of poor households. In short, the richer gain more from the environment even if it represents only $11 \%$ of their total income. This result contradicts somehow the theory that forest products are more important for the poor and may lead to further questions. For instance analyzing NTFP and livelihood security in South Africa, Shackleton $\&$ Shackleton ${ }^{26}$ found that poorer households used and benefited more from these products than did the wealthier. This apparent differing situation may be due to the difference in environmental and access facilities of the communities knowing that in remote areas the production costs may be higher and hardly afforded by the poorer households.

Figure 10 presents the influence of age, years of education, size of the household and region on household income. The results show that age of the head of household (A) influences household income, especially on agriculture where middle age ranks first with about XAF 1.6million (USD 2,909) per year followed by old (XAF 1.3million/ USD 2,364) and last youth (XAF 1.2million/USD 2,182). The same trend is observed for both environmental and other source of income category. On the other hand, years of education of the head of household (A) also impacts the level of household income. For agriculture the correlation is going up gradually; the more educated the head of household, the higher the income. For environmental 
income, the primary level of education is better than illiterate and the trend goes down from primary to secondary and university. But for other categories a household head with university grades earns 6 times (XAF 1.2million/USD 2,182) more than a former primary school pupil (XAF 250,000/USD 455). Surprisingly the illiterate class generates more income than primary. In general there is a positive correlation between the household size and the household income.

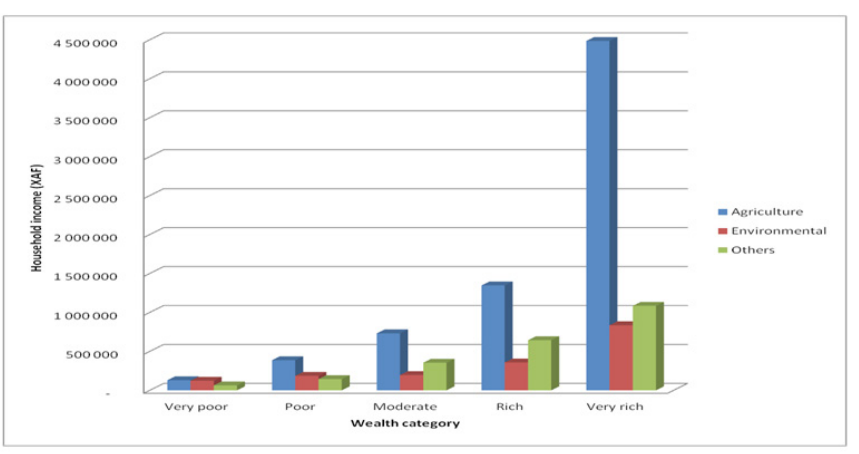

Figure 9 Average total annual household income by wealth categories (quintile method)

As shown in Table 5, there is a significant difference on total annual income of the households interviewed in the three regions (Sig. $0.000<0.05 \%$; Sig. $0.000<0.05 \%$; Sig. $0.004<0.05 \%$ ). The South ranked first (XAF 2,938,172/USD 5,342), Southwest second (XAF 2,702,388/USD 4,913) and East last (XAF 582,905/USD 1,060). The post hoc test following the Anova test revealed that only the East villages were significantly different from the villages of the two other regions $(\mathrm{F}=5.620 ; \mathrm{dl}=472 ; \mathrm{p}=0.004)$. The same table characterized the statistical differences between the 3 main household income sources for the different regions. Thus, only South and Southwest are significantly different $(\mathrm{F}=8.2 ; \mathrm{dl}=462 ; \mathrm{p}=0.0)$ on environmental income while East is negatively different from the two others on agricultural income $(\mathrm{F}=16.07 ; \mathrm{dl}=465 ; \mathrm{p}=0.0)$ with a $05 \%$ margin of error. Meanwhile, the third category "other income source" does not vary significantly $(\mathrm{F}=1.9 ; \mathrm{dl}=440 ; \mathrm{p}=0.1)$ among the three regions.

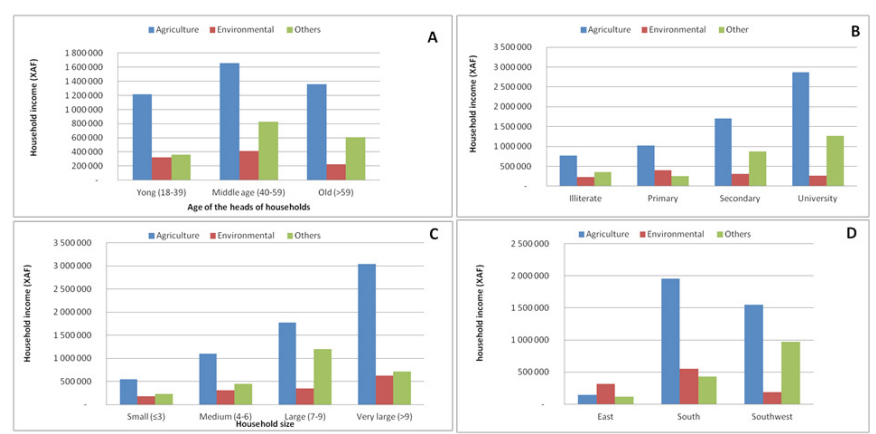

Figure 10 Impact of age (A), years of education (B), household size (C) and region (D) on household's income.

The Pearson Test (Table 6), aiming at evaluating the correlation between an independent quantitative variable (X) and a dependent quantitative variable $(\mathrm{Y})$, shows that agricultural $(\mathrm{r}=0.027$; $\mathrm{p}=0.566>0.05)$, environmental $(\mathrm{r}=-0.030 ; \mathrm{p}=0.521>0.05)$ and 'other' category $(\mathrm{r}=0.023 ; \mathrm{p}=0.627>0.05)$ income are not affected by the age of the head of household. Meanwhile, income from agriculture $(\mathrm{r}=0.198$; $\mathrm{p}=0.000<0.05)$ and 'other' category $(\mathrm{r}=0.112 ; \mathrm{p}=0.018<0.05)$ are influenced by the education level of the head of household but not income from environment $(r=0.005 ; p=0.908>0.05)$. For the household size, there is a correlation between agricultural income $(\mathrm{r}=0.310$; $\mathrm{p}=0.000<0.05)$ and environmental income $(\mathrm{r}=0.127 ; \mathrm{p}=0.006<0.05)$ but not 'other' income category $(r=0.084 ; \mathrm{p}=0.078>0.05)$. Thus, the higher the number of household members, the higher the household income.

Table 5 Statistical comparison of the main sources of household income

\begin{tabular}{lllllll}
\hline Indicator & Region & $\mathbf{n}=$ & Means $/ \mathbf{X}$ & Test F & P value & $<\mathbf{0 . 0 5 = *}$ \\
\hline \multirow{2}{*}{ Agricultural income } & East & 81 & 150,794 & & & \\
& South & 167 & $1,965,581$ & 16.078 & 0 & $*$ \\
& Southwest & 218 & $1,582,537$ & & & \\
Environmental income & East & 82 & 317,392 & & & $*$ \\
& South & 167 & 557,483 & 8.272 & 0 & \\
Other income & Southwest & 214 & 192,970 & & & \\
& East & 81 & 117,997 & & & \\
Sotal income & South & 158 & 457,350 & 1.999 & 0.137 & \\
& Southwest & 202 & $1,071,010$ & & & \\
& East & 82 & 582,905 & & & \\
& South & 168 & $2,938,172$ & 5.62 & 0.004 & \\
& Southwest & 223 & $2,702,388$ & & & \\
\hline
\end{tabular}

Table 6 Statistical comparison of factors influencing household income

\begin{tabular}{llllll}
\hline Correlation & Correlation & $\mathbf{N}=$ & $\mathbf{R}$ & P value & $<0.05=*$ \\
\hline \multirow{3}{*}{ Age } & Agriculture income & 466 & 0.027 & 0.566 & - \\
& Environmental income & 463 & -0.03 & 0.521 & - \\
& Total income & 473 & 0.021 & 0.646 & - \\
\hline
\end{tabular}


Table Continued....

\begin{tabular}{llllll}
\hline Correlation & Correlation & $\mathbf{N}=$ & $\mathbf{R}$ & P value & $<\mathbf{0 . 0 5}=*$ \\
\hline \multirow{3}{*}{ Education } & Agriculture revenue & 466 & $0.198^{* *}$ & 0 & $*$ \\
& Environmental income & 463 & 0.005 & 0.908 & - \\
& Other revenue & $44 I$ & $0.112^{*}$ & 0.018 & $*$ \\
& Total income & 473 & $0.163^{* *}$ & 0 & $*$ \\
Agriculture revenue & 466 & $0.310^{* *}$ & 0 & $*$ \\
Household size & Environmental income & 463 & $0.127 * *$ & 0.006 & $*$ \\
& Other income & 441 & 0.084 & 0.078 & - \\
& Total income & 463 & $0.219 * *$ & 0 & $*$
\end{tabular}

\section{Discussion}

\section{Gendered and opportunistic income}

The environmental income was found globally higher in the South villages led by Medjeng (Figure 6). The case is particularly interesting because though being remote from the main cities of Cameroon, the village is located close to the border with Gabon. This suggests that, apart from the road infrastructure that plays a key role in forest and agricultural goods trade, the sub-regional market demand can be a strong incentive. Akom-Ndong makes second because the village is adjacent to the Dja national park and benefits from a declared sport hunting area, in addition to the improved quality of the Djoum-Mintom road. Meanwhile, Likombe and Bombe Bankundu are the two villages registering the lowest average income from environmental products, in spite of being located on a tarred road for the first and close to Buea city for the second. It is recognized that poor transport infrastructure limits the distribution of goods, as well as cash income for household because, as stated by $\mathrm{FAO},{ }^{27}$ food finally does not reach all those who are most in need. However, other factors can influence environmental income. The performance of Medjeng village, suggests that the connection with the regional market and eventually the international market is an additional determinant in valuing the production of rural people as underlined by Sill et al. ${ }^{17}$ However, for the profit of rural communities, the resources should still be available and producers should have post harvesting knowledge for efficiency. ${ }^{28}$ While it has been considered that the production cost of NTFPs was negligible as local people had access to them in the wild, local communities acknowledge investing increasingly in time and labour to make these products available given that the distance to the forest has been increasing. Especially women have to spend more time away from home. Similar results were obtained by Awono et al..$^{28}$ who found that in some villages women were covering an average distance of 100 to 120 minutes into the forest to harvest NTFPs. Forest land tends to be farther away from the village settlements, imposing additional efforts to women who are already saturated with households' and farm work activities. In Pygmy communities (Baka and Bagyeli or Bakoela) people feel comfortable by leaving the village for weeks during the production season of demanded NTFPs like bush mango (Irvingia spp.) or ndjansang (Ricinodendron heudelotii). Conversely, this situation has negative effects on the household stability. For instance children may stop going to school or lack parental care if they stay at home. Another concern is the management of their production during the camping period of Baka for NTFP harvest. It was reported that Bantu with improved livelihoods were likely to barter the largest share of the Baka's production with low quality alcoholic drinks and minimal quantities of food, including rice and salt. Baka families getting back home after weeks or months in the forest were reported to be somehow disconnected. They have no food reserves available and the little money received from forest goods is promptly spent on alcohol, annihilating their capacity to start over production Awono et al. ${ }^{28}$ In the end, like in the studied villages in the East, the household economic contribution of NTFPs tends to be relatively high but low in absolute terms compared to other household sources of income, like agriculture. The result is then consistent with the idea that NTFPs are particularly important during hard times as subsistence and economic buffer. However, as mentioned by Shackleton \& Pandey, ${ }^{29}$ the management practices on NTFPs are yet to be adequate and furthermore, related support services are very weak or inexistent. Thus NTFP collection remains a traditional activity with a low productivity Awono et al. ${ }^{30}$

It is also worthy noticing that the economic profile of the studied villages is quite different. While environmental products are more present in households' income in the East followed by the South, business and wage labour activities are particularly important in the Southwest. Agriculture is common to all the regions. Table 2 shows that about $40 \%$ of the villages across our sample have access to better infrastructure and socio-economic development. More than half of them are in the Southwest region. Villages with higher environmental income are those with a larger forestland area controlled by the household (Table 2). The villages with the highest total household income are those focusing on agricultural production with an average annual income exceeding XAF 3million (USD 5,455) (Figure 2). These results suggest that, apart from the East villages consisting of Baka people, environmental products in general and ordinary NTFPs in particular are only playing a secondary role in the household economy. However, as noted by Hickey, ${ }^{31}$ these uncultivated resources clearly play a direct provisioning role in household food baskets, thus deserve serious attention for improvement.

Our findings provide empirical support for further forest policy for rural livelihood improvement by NTFP valuation. Given that the majority of rural households in Cameroon are under high pressure in September with the start of the new school year, a great attention has been put on NTFPs by women and children to generate additional income. ${ }^{32-34}$ The harvest of NTFPs is an ancient activity mainly controlled by women. Along the same line, assessing how men and women access, manage, and use different forest products in the world tropical forest, Sunderland et al. ${ }^{2}$ found that Africa was the only region in the world where women dominated the NTFP sector. Although many NTFPs have not yet acquired an attractive market value, they support people's livelihoods through subsistence, especially during the lean season until the next agricultural harvest season. Similarly, a number of studies ${ }^{31,35}$ underlined that wild food resources are known to act as important nutritional and livelihood safety nets during periods 
of shortage, shock or livelihood disruption. In the South of Cameroon, women underlined that they feed their family with uncommon forest products like the leaves of baobab (Adansonia digitata), ayous (Triplochiton scleroxylon) or asse (Afzelia africana) during severe dry seasons which results in shortage of vegetables. It was also the case for wild yam (Dioscorea villosa) locally a synonym of product of the poor. This happens usually in strict intimacy in order to preserve the dignity of the family. Thus, the importance of NTFPs goes far beyond the income generated. Similarly to what was pointed out by Wunder ${ }^{36}$ rather than constructing a strong socio-economic growth, NTFPs will remain an alternative solution to income shortfalls until strategic orientations are put in place to go beyond wild harvests by advancing domestication and processing of the growing market for specific products.

\section{NTFPs diversity and regulations}

Forests are reportedly being coveted by various activities, creating some doubts on sustainable management. In fact, forests adjacent to community settlements used to be exploited by logging companies and agro-industries without any consideration for local peoples' needs, degrading their natural potential along the line. NTFPs like other environmental products deserve a long term planning and convincing actions to increase their contribution to the household economy in rural zones. After the government has authorized the communities to own and manage officially community forests to support both conservation and economic benefits, no substantial difference has been observed on NTFPs valuation. ${ }^{18}$ Despite the challenges behind NTFP exploitation in the humid forest zone of Cameroon, the results obtained suggest that these products are part of the income diversification strategy to make their local economy dynamic in supporting people living conditions, providing them with food they deserve/prefer and additional income as much as possible. The availability of these products associated with some incentives like production equipment, processing material or policy facilities can pave the way for positive change on the ground. As agreed by Laird et $\mathrm{al}^{7}$ Laird \& Wynberg ${ }^{37}$ and Shanley et al. ${ }^{16}$ some critical preconditions are to be fulfilled, including a favorable law and environmental policy, well-developed and accessible markets, secure tenure, and a well-managed resource base. Furthermore, contrary to the idea that it could be important to engage the wealthier income groups in development of conservation strategies because they use the greater volumes of NTFPs, ${ }^{38}$ development and conservation projects should rather choose collective strategies integrating all community members willing to improve practices and uses because there is a chance for shifting from one class to another over time.

Due to the diverse varieties of the sub-products obtained from NTFPs, a great percentage of households in rural areas harvest NTFP for self-consumption or trade. Many NTFPs are forest plant-based products from trees, including roots, barks, resins, leaves, nuts, fruits, etc. Meanwhile forest plant-based products not from trees also exist and range from herbs, mushrooms, shrubs, insects or vine. They extend the list of NTFPs and contribute to secure local communities from hunger and health problems. In general little attention has been paid on the distinction between forest plant-based products from trees and non-forest plant-based products from trees. An increased proportion is harvested outside forests, which should be acknowledged for improved forest policies. In fact, the recognition that part of forest products are harvested in fallows or plantations as associated plants should lead to a different view on the policy framework applied to this category of products. If they were found in plantation it was due to the tolerance of the populations during agricultural operations.
Their presence in fallows may go to the same line but should also be explained by the decrease in competition among the different species. Moreover, it can be argued that forest plant-based products not from trees, should not be regulated like forest plant-based products from trees as the impact of their exploitation has nothing to do with forests or trees that justify the spirit behind conservation forest policies resulting from international conventions that tend to focus on forest attributes.

\section{Impact of improved infrastructure on NTFPs production}

Rural people find themselves in a situation where they have to decide on their principal livelihood activities with regard to available opportunities. Education level and age of the head of household are likely associated with that choice. Similar results were obtained by Ifeanyi-Obi \& Matthews-Njoku ${ }^{25}$ in the analysis of the major socioeconomic factors affecting livelihood activities in Nigeria. The improvement of physical infrastructures in terms of roads or markets generates irrefutably additional options, including riding motor bikes, developing petty trade with manufactured products, travelling more easily to the urban markets to sell agricultural or environmental goods or selling them in the village because traders are able to come right there. It may be expected that people put more effort on available NTFPs to generate more income but the discussions with producers suggest the priority for products generating cash in a short period of time. As such more effort is invested in agricultural products like groundnut that can be sold and also stored for a long period. On the other hand, it was indicated in East and South regions that some NTFPs like njansang or bush mango may be available in some ecosystems but not all women possess the necessary technology (knowhow) to take advantage of. In addition, the production cycle of some NTFPs is irregular while production techniques are quite challenging ( 2 to 3years without fruiting). Due to taste and cultural functions as pointed out by Arnold \& Ruiz-Perez, ${ }^{10}$ some community members would struggle to harvest at least for self-consumption, no matter the distance to cover in the forest.

Likewise, some wild products (like wild yam) were reported to be back on the table of the poorest households to fight against famine during difficult years. In fact, after macabo (Xanthosoma sagittifolium Schott) able to yield 40 tons/ha was introduced from Latin America in the 19th century, wild yam was progressively abandoned by local communities. It is clear that NTFPs were widely used by local populations in the past for various reasons and needs; therefore the choices of rural communities were not emotional but realistic. The adoption of new crops, like okra and cocoyam leaves, compared to asse or ayous leaves, was linked to taste preferences and higher productivities. During the period of bush fires, farms were protected with cleaned lines, while it was difficult to protect NTFPs in the forested areas. As a result many NTFPs disappeared progressively and became difficult to find for community members. Another argument is that contrary to local forest products, introduced crops have been the target of genetic improvement for centuries by researchers and farmers. Households can associate many food crops (groundnut, cassava, maize, okra, melon, plantain, etc.) on the same farm, saving time for farmers who knew that a day was only 12 hours while they were involved in so many tasks for the livelihoods. Such situation tends to reduce the collectors concentration on a limited number of forest products.

Finally, based on the context of permanent pressure from a myriad 
of household tasks, though not always rewarding, it is understandable that people consider in some communities in Cameroon that women and children are synonym of wealth. ${ }^{39}$ Actually, this representation is associated with the idea that the size of the family is synonym of labour force. More importantly, the elders in that context consider the involvement of children into household labour to be the training process for a stable society; bringing somehow in mind the famous statement from ${ }^{40}$ the child is father to the man.

\section{NTFP management in the study sites}

Contrary to other regions, environmental income contribution in the Southwest is relatively low. This result is not surprising because the Southwest region has experienced the highest deforestation rate in Cameroon $(0.11 \%$ compared to 0.03 at the national level) with the establishment of many agro-industries for decades. ${ }^{28}$ Even protected areas of the region, due to State laxity, have not survived the pressure of a population enriched by migrants from arid regions like the Northwest. ${ }^{28}$ On the contrary forest cover is still important in the South and the East. However community members of the South are active in agriculture and in forest products exploitation (especially bush meat) for trade. In the East, our results cannot be considered as representative of the region as the two villages selected for this study consist exclusively of Baka, who are regularly cheated by Bantu and end up benefiting less from natural resources.

In Cameroon, like in other Congo Basin countries, agriculture is viewed as the main cause of deforestation. ${ }^{9}$ This is also a reality across our study areas as the targeted practices of slash and burn for extensive mixed farming, fuelwood extraction, charcoal production, opening of new fields for cocoa or oil palm plantations, felling of palm trees for palm wine production, and others, were reported to take place all the villages surveyed. Other activities like gathering honey also lead to deforestation or forest degradation through the use of bush fire to reduce bee attacks. Similarly, Awono et al. ${ }^{41}$ support that pressures on forest, are a combination of factors of both external and internal origin in the villages. It has been reported in many cases that villagers were pushed by elites to practise illegal logging. In addition, forests adjacent to community settlements have been exploited by logging companies and agro-industries without clear consideration of local people's needs thus degrading their natural potential along the line. In a context where there is an increasing portion of NTFPs generated from both forest and non-forest lands contributing to health, income and food security, ${ }^{31}$ the role of rural people in the domestication of NTFPs should be recognized officially and reinforced through a strategic forest policy implementation plan. ${ }^{18}$ Similarly, the increase in deforestation and forest degradation as seen across our study sites militates in favour of an urgent support from the national and international community before it is too late. NTFPs remain part of an income diversification strategy supporting livelihoods. The availability of these products associated with innovative incentives in terms of improved vegetal material, production equipment, processing material or policy facilities can pave the way for positive changes on the ground. Overall, NTFPs like other environmental products deserve a long term planning and convincing actions at least to maintain their contribution to the rural household economy.

Cameroon, as well as other Congo Basin countries, is increasingly exposed to food crises and famines amplified by climate change associated with drought, pests and other diseases having a direct impact on production systems. In a context where hunger is projected to worsen over the next two decades in Africa unless peace, improved governance and economic development become a reality, ${ }^{27}$ our results suggest that serious attention should be granted to NTFPs to ensure food security.

\section{Conclusion}

The results obtained show that environmental products are a diverse and complementary to the livelihoods for poor, medium and rich households in the humid forest zone of Cameroon. Almost all categories harvest such products for food, medicine, income or other services. However, except for one village out of 13, these products fail to compete with other opportunities to guarantee a sustainable livelihood in rural areas. Contrary to the usual assumption that NTFPs are the products of the poor, our study reveals that though they represent a higher part of the income of the poorer households, in absolute value the richer households benefit more. Wealth in the rural context of Cameroon, as shown by our data, is closely linked to agricultural activities, thus associated with accelerated deforestation. The richer households of the sample are among those practicing agriculture, education and age being positive driving factors. Investigating on the contribution of NTFP to livelihood of the forest poor in the Southwest of Cameroon, ${ }^{38}$ reached a similar conclusion: livelihood diversification away from natural resource-based activities presents a means for increased livelihood security. However, beyond the income contribution of NTFPs to household economy, the decline in NTFP production remains a concern. Our study suggests that, without including other type of environmental goods like fuel wood or bush meat, NTFPs represent less than $5 \%$ of the average annual household income in 11 out of 13 villages of our sample, in which more that $40 \%$ derives from non-forest land in the Southwest region for instance. Likewise, the increased distances to the edge of forest for NTFP harvest leads to additional costs. As noted by Awono et al. ${ }^{41}$ the multiple activities carried out by smallholders and agro-industries are increasingly destroying environmental goods. Thus, a collective hard-work should be initiated about agricultural improved practices and domestication of forest products to strengthen the production of NTFPs for the expansion of trade, ${ }^{42}$ which can better support livelihoods in local communities. Overall, NTFPs will probably not be able to save the tropical forest nor alleviate poverty in rural areas, but strategic and innovative support from local governments and international donors can reverse the decline in production of the most demanded products for food, medicine and various services for improved livelihoods through domestication and processing.

\section{Acknowledgements}

The authors gratefully acknowledge the contribution of the Global Comparative Project team members under the Center for International Forestry Research (CIFOR) to the research presented here. Thanks go to three anonymous reviewers for their valuable comments on this paper, and to all farmers who were interviewed during the survey. Henri Owona deserves special thanks for his assistance in data management and analyses.

\section{Conflict of interest}

Authors declare that there is no conflict of interest.

\section{References}

1. Ruiz Perez M, Belcher B, Achdiawan R, et al. Markets drive the specialization strategies of forest peoples. Ecology and Society. 2004:9(2) 
2. Sunderland $\mathrm{TCH}$, Ndoye O. Forest products, livelihoods and conservation: case studies of non-timber forest product systems. Bogor: SMK Grafika Desa Putera; 2004. p. 1-490.

3. Peters CM, Gentry AH, Mendelsohn RO. Valuation of an Amazonian rainforest. Nature. 1989;339:655-656.

4. FAO. The major significance of "minor" forest products - the local use and value of forest in the West African humid forest zone. Rome: Food and Agriculture Organization of the United Nations; 1990.

5. FAO. Données statistiques des produits forestiers non-ligneux du Cameroun, Programme de partenariat CE-FAO (1998-2001). Projet GCP/INT/679/EC, FAO/ European Commission, Cameroon; 1999.

6. Vivien J, Faure JJ. Fruitiers sauvages d'Afrique (Espèces du Cameroun) Paris: Saint-Céneré, Editions Nguila-Kerou Ministère Français de la Coopération et CTA. 1996.

7. Laird SA, Ingram V, Awono A, et al. Bringing Together Customary and Statutory Systems: The Struggle to Develop a Legal and Policy Framework for NTFPs in Cameroon. In: Laird SA, McLain R, Wynberg RP, editors. Wild Product Governance: Finding Policies that Work for Non-Timber Forest Products. UK: Earthscan; 2010. p. 53-70.

8. Ndoye O, Tieguhong JC. Forest resources and rural livelihoods: the conflict between timber and non-timber forest products in the Congo Basin. Scandinavian Journal of Forest Research. 2004;19(4):36-44.

9. Ndoye O, Kaimowitz D. Macroeconomics, markets and the humid forest of Cameroon, 1967-1997. Journal of Modern African Studies. 2000;38(2):225-253

10. Arnold JEM, Ruiz-Perez M. The role of non-timber forest products in conservation and development. In: Wollenberg E, Ingles A, editors. Incomes from the forest: methods for the development and conservation of forest products for local communities. Bogor: CIFOR; 1998. 17-42p.

11. Chreckenberg K, Awono A, Degrande A, et al. Domesticating indigenous fruit trees to reduce poverty. Forests, Trees and Livelihoods 2006;16:35-51.

12. Tchoundjeu Z. Update on the domestication of indigenous fruit trees and medicinal plants of West and Central Africa. Yaoundé: In: Actes de la cinquième conférence sur les écosystèmes des forêts denses et humides d'Afrique centrale (CEFDHAC); 2004. p. 219-223.

13. Guariguata MR, Sist P, Nasi R. Multiple use management of tropical production forests: how can we move from concept to reality? Fores Ecology and Management. 2012;263:170-174.

14. Hughes R, Flintan F. Integrating conservation and development experience: a review and bibliography of the ICDP Literature Biodiversity and Livelihoods Issue Paper 3. London, UK: International Institute for Environment and Development. 2001. p. 1-24.

15. Nasi R, Frost PGH. Sustainable forest management in the tropics: is everything in order but the patient still dying? Ecology and Society. 2009;14(2):1-12.

16. Shanley P, Pierce AR, Laird SA, et al. From lifelines to livelihoods: Nontimber forest products into the twenty-first century. In: Pancel L, Köhl M, editors. Tropical Forestry Handbook. Germany: Springer; 2015. p. 1-50.

17. Sills E, Shanley P, Paumgarten F, et al. Evolving perspectives on nontimber forest products. In: Shackleton S, Shackleton C, Shanley P, editors. Non-timber forest products in the global context. Berlin: Springer; 2011. p. 23-54.

18. Awono A, Chindjang M, Patrice L. Will the proposed forest policy and regulatory reforms boost the NTFP sector in Cameroon? International Forestry Review. 2016;18(s1):78-92.

19. UNDP. Promoting Sustainable Livelihoods: A Briefing Note Submitted to the Executive Committee. United Nations, New York, USA; 1997.
20. UNDP. Human development report. New York: Oxford University Press; 2000.

21. Whitehead A, Kabeer N. Living with uncertainty: gender, livelihoods and pro-poor growth in rural sub-Saharan Africa. IDS working paper 134. Institute of Development Studies. Brighton, Sussex BN1, England; 2001. 1-37p.

22. Sunderlin WD, Larson AM, Duchelle A, et al. Technical Guidelines for Research on REDD+ Project Sites. Bogor: CIFOR; 2010. p. 1-137.

23. De Wasseige C, De Marcken P, Bayol N, et al. Les Forêts du Bassin du Congo: Etat des Forêts 2010. Luxembourg: Office des publications de l'Union Européenne; 2012. p. 1-280.

24. Levang P, Lescuyer G, Noumbissi D, et al. Does gathering really pay? Case studies from forest areas of the East and South regions of Cameroon. Forests, Trees and Livelihoods. 2015;24(2):128-143.

25. Ifeanyi-Obi CC, Matthews-Njoku EC. Socio-economic factors affecting choice of livelihood activities among rural dwellers in Southeast Nigeria. IOSR Journal of Agriculture and Veterinary Science. 2014;7(4):52-56.

26. Shackleton $\mathrm{C}$, Shackleton $\mathrm{S}$. The importance of non-timber forest products in rural livelihood security and as safety nets: a review of evidence from South Africa. South African Journal of Science. 2004;100:658-664.

27. FAO. Food security and agricultural development in sub-Saharan Africa Building a case for more public support. Policy brief no.1. Rome, Italy; 2005. p. 1-7.

28. Awono A, Tambe AA, Owona H, et al. REDD+ around Mount Cameroon, southwest region of Cameroon. In Sills EO, Atmadja S, Sassi $\mathrm{C}$, et al. editors. REDD+ on the ground. Bogor, Indonesia: Center for International Forestry Research (CIFOR); 2015.

29. Shackleton CM, Pandey AK. Positioning non-timber forest products on the development agenda. Forest Policy Economics. 2014;38:1-7.

30. Awono A, Ndoye O, Preece L. Empowering women's capacity for improved livelihoods in non-timber forest product trade in Cameroon International Journal of Social Forestry. 2010;3(2):151-163.

31. Hickey GM, Pouliot M, Smith-Hall C, et al. Quantifying the economic contribution of wild food harvests to rural livelihoods: A globalcomparative analysis. Food Policy. 2016;62:122-132.

32. Awono A, Eba'a Atyi R, Foundjem-Tita D, et al. Vegetal non-timber forest products in Cameroon, contribution to the national economy. International Forestry Review. 2016;18(S1):66-77.

33. Ingram V, Schure J, Tieguhong JC, et al. Gender implications of forest product value chains in the Congo basin. Forests, Trees and Livelihoods. 2014;23(1-2):67-86.

34. Nkem J, Kalame FB, Idinoba M, et al. Shaping forest safety nets with markets: Adaptation to climate change under changing roles of tropical forest in the Congo Basin. Environmental Science \& Policy. 2010;13:498-508.

35. Wunder S, Börner J, Shively G, et al. Safety nets, gap filling and forests: a global-comparative perspective. World Development. 2014;64(S1):29-42.

36. Wunder S. Poverty alleviation and tropical forests. What scope for synergies? World Development. 2001;29(11):1817-1833.

37. Laird SA. Bioscience at a crossroads: access and benefit sharing in a time of scientific, technological and industry change: the pharmaceutical industry. Montreal: Secretariat of the Convention on Biological Diversity; 2013.

38. Ambrose-Oji B. The contribution of NTFPs to the livelihoods of the 'forest poor': evidence from the tropical forest zone of south-west Cameroon. International Forestry Review. 2003;5(2):106-117. 
39. Laburthe-Tolra P. Paris: Initiations et sociétés secrètes au Cameroun: les mystères de la nuit. 1985. p. 1-437.

40. Wordsworth W. My heart leaps up. New York: Academy of American Poets. 1873 .

41. Awono A, Somorin OA, Atyi RE, Levang P. Tenure and participation in local REDD+ projects: Insights from southern Cameroon. Environmental Science and Policy. 2014;35:76-86.
42. Homma AKO. The dynamics of extraction in Amazonia: a historical perspective. In: Nepstad D, Schwartzman S, editors. Non-timber forest products from the tropical forests: evaluation of a conservation and development strategy, Advances in economic botany. Bronx, USA: NY Botanical Garden; 1992. p. 23-31. 